\title{
Examining Paid Mobile Application Customer Loyalty: The Moderating Effect of Switching Costs
}

\author{
Wen-Tsung $\mathrm{Wu}$ \\ Department of International Business, National Dong-Hwa University \\ No. 1, Sec. 2, Da Hsueh Rd. Shoufeng, Hualien 97401, Taiwan \\ Tel: 886-3863-3042Ｅ-mail: 810232011@ems.ndhu.edu.tw
}

Chie-Bein Chen

Department of International Business, National Dong-Hwa University

No. 1, Sec. 2, Da Hsueh Rd. Shoufeng, Hualien 97401, Taiwan

Tel: 886-3863-3048Ｅ-mail: cbchen@mail.ndhu.edu.tw

\author{
Chiao-Chen Chang \\ Department of International Business, National Dong-Hwa University \\ No. 1, Sec. 2, Da Hsueh Rd. Shoufeng, Hualien 97401, Taiwan \\ Tel: 886-3863-3058Ｅ-mail: aka@mail.ndhu.edu.tw
}

Received: July 7, 2016 Accepted: July 21, 2016

doi:10.5296/ber.v6i2.9837 URL: http://dx.doi.org/10.5296/ber.v6i2.9837

\begin{abstract}
The mobile application industry has more actions and services in recent years due to consumer demand. The purpose of this study is to explain the relationships among perceived value, satisfaction, and customer loyalty in the paid mobile application industry. Moreover, this study develops and tests a conceptual model that offer a value perspective in understanding customer loyalty toward paid mobile applications. To achieve this aim, perceived value and customer satisfaction must be measured and "switching costs" identified. This study also takes a value component perspective from Bernardo, Marimon and del Mar Alonso-Almeida (2012) to confirm how the two types of switching costs (monetary vs. nonmonetary switching costs) moderate the link in perceived value, satisfaction, and loyalty
\end{abstract}


in the instance of a paid entertainment mobile application. The results from an online survey indicate that the switching costs had a moderating effect on the relationship between perceived value and loyalty, and the satisfaction and loyalty of using paid mobile applications. With respect to the findings, the moderating effect of switching cost play a critical role in determining customer loyalty of paid mobile applications. It also revealed that nonmonetary switching costs has more importance than monetary switching costs in engendering loyalty, since monetary contains price in the download paid mobile applications, which provides negative outcomes among the relationship of perceived value, satisfaction, and loyalty. In the conclusion, the implications of these findings are discussed.

Keywords: Mobile application; Loyalty; Value; Satisfaction; Switching cost

\section{Introduction}

Mobile commerce, also known as M-Commerce, is basically any e-commerce done in a wireless environment, especially via the Internet (Turban and King, 2003). With the growing number of applications available in online mobile application markets, and given the advancements in smart phone capabilities, users of these phones are now able to take advantage of a wide range of applications (apps) nearly anywhere at anytime (Satyanarayanan, 2005). The idea of ubiquitous mobile commerce has been around for at least a decade ever since mobile phones began to be rapidly adopted by users all over the world, especially in developing countries where landline-based phone services were almost non-existent. Simultaneously, businesses have decided to provide mobile applications and web services over the Internet and have nurtured an increasing number of mobile application users. By the end of 2012, there will be one billion active mobile application users in the world (Learn Everywhere, 2012).

While users are able to make use of a growing number of increasingly diverse apps, they still need to frequently update and organize their phone's menu as well as spend time searching and selecting the apps they wish to use (Shin, Hong, and Dey, 2012). Amongst the most popular mobile applications in the setting of business-to-consumer mobile applications are in the category of communications and entertainment (Wei, 2008). For example, the growing attractiveness of free social network service apps (e.g., Twitter, Facebook, YouTube) and location-based service apps (e.g., FourSquare and Google Maps) allows users to retrieve large amounts of content about their environment and to locate their friends (Shin, Hong, and Dey, 2012). Even among these apps services avid users, just $21 \%$ paid for the app on their smart phone or tablet computer. That amounts to $1 \%$ of the entire adult population (Fu et al., 2013). Previous studies have also shown that perceived value was a better predictor for use or adopting IS that was not free-of-charge (e.g., Lu and Hsiao, 2010). Therefore, looking toward the future, it is important to realize that paid mobile application such mobile games may attach different customers which perceived different value components of perceived value to these benefits. Mobile games are one of the largest paid mobile application areas and one where users are often willing to pay for services (Penttinen, Rossi, and Tuunainen, 2010). A very successful example of promoting a paid mobile application with a free basic version is "Angry Birds" (Waldner, Zsifkovits, and Heidenberger, 2013). Based on such studies, this 
study looks into loyalty when paying for mobile games.

However, as mobile services become more popular and people can use them virtually anywhere, research on the effect of switching costs is gaining more attention. Although the moderating effect of switching costs on the satisfaction-loyalty relationship has been researched, its impact on the relationship between perceived value and loyalty has essentially been ignored in mobile commerce contexts. Accordingly, the main purpose of this study is to explore from a value perspective to help service marketers understand what factors impact user satisfaction and loyalty, and how best to take measures with the effects of switching costs to retain their customers.

\section{Literature Review and Hypothesis Development}

\subsection{Mobile Applications}

As mobile applications have become a significant part of individual and organizational life, research on mobile commerce has also studied. Therefore, a number of studies have attempted to predict mobile applications use on mobile devices (Ha, Yoon, and Choi, 2007). For example, Ha and Choi (2007) discussed the user adoption under mobile broadband wireless access environment. Indeed, mobile applications are software or applications for the purpose of performing specific tasks for the user and are suited to run on mobile phones, smartphones or electronic devices.

Mobile game (m-game) is a potential market generating revenues for service providers. M-game can completely offload game engine requiring large computing resource (e.g., graphic rendering) to the server in the cloud, and gamers only interact with the screen interface on their devices demonstrates that offloading (multimedia code) can save energy for mobile devices, thereby increasing game playing time on mobile devices (Kottari et al., 2013).

On the other hand, some mobile applications have used in the situations of monetary switching costs and nonmonetary switching costs. Users perceived what degree of switching costs in using mobile games may determine perceived value, satisfaction, and loyalty. Thus, following past research findings, this study attempts to from a value perspective to explore the antecedents of perceived value and tests the moderating role of switching costs in the perceived value-satisfaction-loyalty relationship.

\subsection{Loyalty}

Oliver (1999) defined loyalty as "a deeply held commitment to re-buy or re-patronize a preferred product/service consistently in the future, thereby causing repetitive same-brand or same brand-set purchasing, despite situational influences and marketing efforts having the potential to cause switching behavior." Most researchers combined behavior-based loyalty and attitude-based loyalty as one constructs measuring brand loyalty while Baldinger and Rubinson, in 1996. Baldinger and Rubinson (1996) found that while loyalty can be measured by different means, repeat purchases have been one of the most frequently used methods. That is, loyalty refers to repeated support given to a single firm. This behaviour also can be 
influenced by habits, by other people, or by a random choice (Nguyen, Leclerc, and LeBlanc, 2013). Loyalty also represents the intention to repurchase, the desire to recommend, a tolerance for a higher price, and the desire to purchase other products with (from) an institute (Chang and Fong, 2010).

On the other hand, loyalty is a major driver of success in electronic commerce (Reichheld and Schefter, 2000). Loyal customers often will, over time, bring in substantial revenues and demand less time and attention from the firms they patronize. Deng et al. (2010) also pointed out that retaining existing customers and strengthening customer loyalty appear to be very crucial for mobile service providers to gain a competitive advantage. Indeed, retaining customers is a financial imperative for any $\mathrm{m}$-commerce vendor ( $\mathrm{m}$-vendor), especially as attracting new customers is considerably more expensive than for comparable, traditional, brick-and-mortar stores. Following the above literature review, this study measures customer loyalty as customers' behavioral intention to continuously use mobile instant messages with their present service providers, as well as their inclination to recommend this mobile application to other persons.

\subsection{Perceived Value}

Zeithaml (1988) offers the most universally accepted trade-off definition of perceived value in the literature. Additionally, perceived value refers to the consumer's overall assessment of the utility of a product based on perceptions of what is received and what is given (Zeithaml, 1988 , p. 14). In the most frequently used approach, value is a relationship between what one benefits and what one sacrifices (see Sánchez-Fernández and Iniesta-Bonilla, 2007). That is, some consumers obtained value from all relevant 'get' and 'give' components, leading to the definition of perceived value. In comparison, some studies have also suggested that viewing value as a trade-off between only quality and price is too simplistic (e.g., Bolton and Drew, 1991). Holbrook (1999) found that it is important to understand the value concept in an integrative approach, because one can understand a given type of value only by considering its relationship to other types of value. Thus, a more sophisticated measure is needed to understand how consumers value products and services and the present study was an attempt to create such a measure (Sweeney and Soutar, 2001). In addition, Sirdeshmukh, Singh and Sabol (2002) argued that customer value is a superordinate goal and loyalty is a subordinate goal, as it is a behavioral intention. Turel and Serenko (2006) further considered that this was inadequate owing to the prevailing definition of perceived value as an overall assessment.

Past research has shown that perceived value was a better predictor of loyalty in the domain of mobile commerce. For example, Deng et al. (2010) indicated that perceived value was positively correlated with mobile instant messages. Indeed, perceived value constitutes one of the most important determinants of loyalty. As a result, the following hypotheses related to perceived value and loyalty can be proposed:

H1. Perceived value positively influences loyalty.

\subsection{Satisfaction}

Customer satisfaction, which refers to "the summary psychological state resulting when the 
emotion surrounding disconfirmed expectations is coupled with the consumer's prior feelings about the consumption experience" (Oliver, 1981). In the online context, Szymanski and Hise (2000) and Evanschitzky et al. (2004) conceptualize satisfaction as the consumers' judgment of their Internet retail experience as compared to their experiences with traditional retail stores. Lin and Wang (2006) revealed that satisfaction in mobile commerce is a consumer's total response to the purchase experiences in a mobile commerce environment. Therefore, in this study, satisfaction is defined as the total consumption perception of consumers when using mobile applications.

The Mediating Role of Satisfaction in the Value-Loyalty Relationship

Perceived value is an important concept, as it is believed to have an influence on satisfaction and loyalty (Yang and Peterson, 2004). Offering higher product/service value can lead to higher customer satisfaction. Furthermore, the mediation effect of satisfaction on the value-loyalty relationship also exists (Chen and Tsai, 2008). In the research into the relationships between perceived value and customer satisfaction, empirical studies of conventional retailers discovered that perceived value positively influences satisfaction in mobile commerce. For example, Lin and Wang (2006) and Turel and Serenko (2006) all revealed that perceived value is positively related to satisfaction. In turn, satisfaction is often considered as an important determinant of customer loyalty (Eggert and Ulaga, 2002). Given the findings of existing research, this study proposes the following hypotheses.

H2. Perceived value is a direct antecedent of satisfaction.

H3. Satisfaction is a direct antecedent of loyalty.

\subsection{Antecedents of Perceived Value}

Sweeney and Soutar (2001) proposed a modified model, and originally perceived value as an assumed functional value that could be decomposed into quality and price value. The epistemic and conditional elements of perceived value were less critical, while specific cases of other types of value could be excluded. As a result, this study treated it as the major perception formed by the dimensions of perceived value and assumed that Sweeney and Soutar's four components would all have a positive effect on the overall perceived value.

\subsubsection{Functional Quality}

Functional quality reflects the 'how' of service performance (Grönroos, 2000). Further, functional quality measures how customers perceive the production and delivery of the service (Razavi et al., 2012). Given that most studies of e-quality and perceived value utilized adaptations of the dimensions of e-quality, which are essentially functional (rather than hedonic) in nature, the following hypothesis was proposed:

H5. The level of functional quality in a mobile application is positively correlated with perceived value.

\subsubsection{Hedonic Quality}

Hedonic quality is defined as the value obtained by a consumer from finding and purchasing 
a particular good or service. This type of quality can be distinguished from purely utilitarian (functional) quality. The impact of hedonic quality has received relatively little attention, especially in the online context. However, some more recent studies have examined aspects of these issues. Ahn, Ryu, and Han (2007) examined the notion of hedonic quality as playing a role in technology acceptance. Following past research findings, this study concluded that hedonic dimensions should be considered by mobile application designs and marketers, and infers that hedonic quality will lead to produce perceived value. Then, this study puts forth the hypothesis:

H6. The level of hedonic quality in a mobile application is positively correlated with perceived value.

\subsection{The Moderating Role of Switching Costs}

While the cost enhances, customers become less sensitive to the satisfaction level (Hauser et al., 1994). Also, market structure influences the effect that switching cost has on the relationship between customer loyalty and customer satisfaction. If the market includes one overwhelmingly large share provider (such as an established fixed-line service provider), the effect of the switching cost on the relationship between customer loyalty and customer satisfaction will be low. Switching costs have often been found to moderate important marketing relationships (e.g., Han and Ryu, 2012). Porter (1998) defined switching costs was defined as "one-time costs facing the buyer when switching from one supplier's product to another's" (p. 10). That is, if the customer perceives value in a particular mobile application, it is likely that s/he will frequent that mobile application on a regular basis, thus becoming familiar with the variety of offerings and services. Further, the type of switching costs could also influence the customer's perception of value. Many researchers agree that switching costs include both monetary expenses and nonmonetary costs (Dick and Basu, 1994, Kim, Kliger, and Vale 2003). Compared to monetary switching costs, nonmonetary costs include time, effort, and psychological stress (Han and Ryu, 2012). With regard to switching costs, it is still possible to distinguish among costs based on costs by simply comparing monetary and nonmonetary costs of the same/similar offerings and services.

Fullerton (2003) found that the positive effects of affective commitment on advocacy (i.e., recommendation and WOM praise) are tremendously diminished by the presence of high monetary and nonmonetary (psychological) switching costs in his study of the mobile phone sector. His study suggested that switching costs significantly affect the relationship between affective commitment and behavioral intentions. Also, Han and Ryu (2012) found that the moderating of switching costs in explaining the effect of satisfaction on loyalty was significant in the offline environment. However, in the online environment, the moderator of switching costs played an important role in explaining the relationship of perceived value, satisfaction, and loyalty (Yang and Peterson, 2004). However, previous results do not clearly show the role played by switching costs with respect to mobile applications use. The current study expects that nonmonetary switching costs are likely to derive more loyalty. Accordingly, the following hypothesis is proposed:

H6a. The relationship between perceived value and loyalty to use mobile applications will be 
higher for users who perceive a lower level of monetary switching costs than for those perceive a higher level of monetary switching costs.

H6b. The relationship between perceived value and loyalty to use mobile applications will be higher for users who perceived a lower nonmonetary switching costs than for those perceived a higher level of nonmonetary switching costs.

H7a. The relationship between satisfaction and loyalty to use mobile applications will be higher for users who perceive a lower level of monetary switching costs than for those perceive a higher level of monetary switching costs.

H7b. The relationship between satisfaction and loyalty to use mobile applications will be higher for users who perceived a lower nonmonetary switching costs than for those perceived a higher level of nonmonetary switching costs.

\section{Methodology}

\subsection{Study Context and Research Design}

Mass communication and entertainment are considered the most attractive categories for mobile applications (Wei, 2008). They are available through application distribution platforms, which are typically operated by the owner of the mobile operating system, such as the Apple App Store, Google Play, Windows Phone Store and BlackBerry App World. Some apps are free, while others have a price. Hence, this study draws on a use-and-gratification framework to examine the expanded use of hybrid switching costs for an example of entertainment applications.

\section{Example game}

Looking at the 300 most popular paid applications, $72 \%$ of downloads are generated by games, while the remaining $28 \%$ of downloads are generated by applications other than games in the Apple App Store for the iPhone. This means that mobile games such as Angry Birds are the most popular entertainment mobile applications (iOSpirations Statistics, 2013) in terms of the number of people participating and their customer loyalty, their willingness to pay, and their intention to use these applications in the future (Liu and Chou, 2008). Therefore, this study applies the case of mobile games to examine the moderating effect of switching costs in the perceived value-satisfaction-loyalty relationship.

\subsection{Conceptual Model}

Fig. 1 shows the research model, which presents the associations among research constructs as well as moderating effects of monetary and nonmonetary switching costs. 


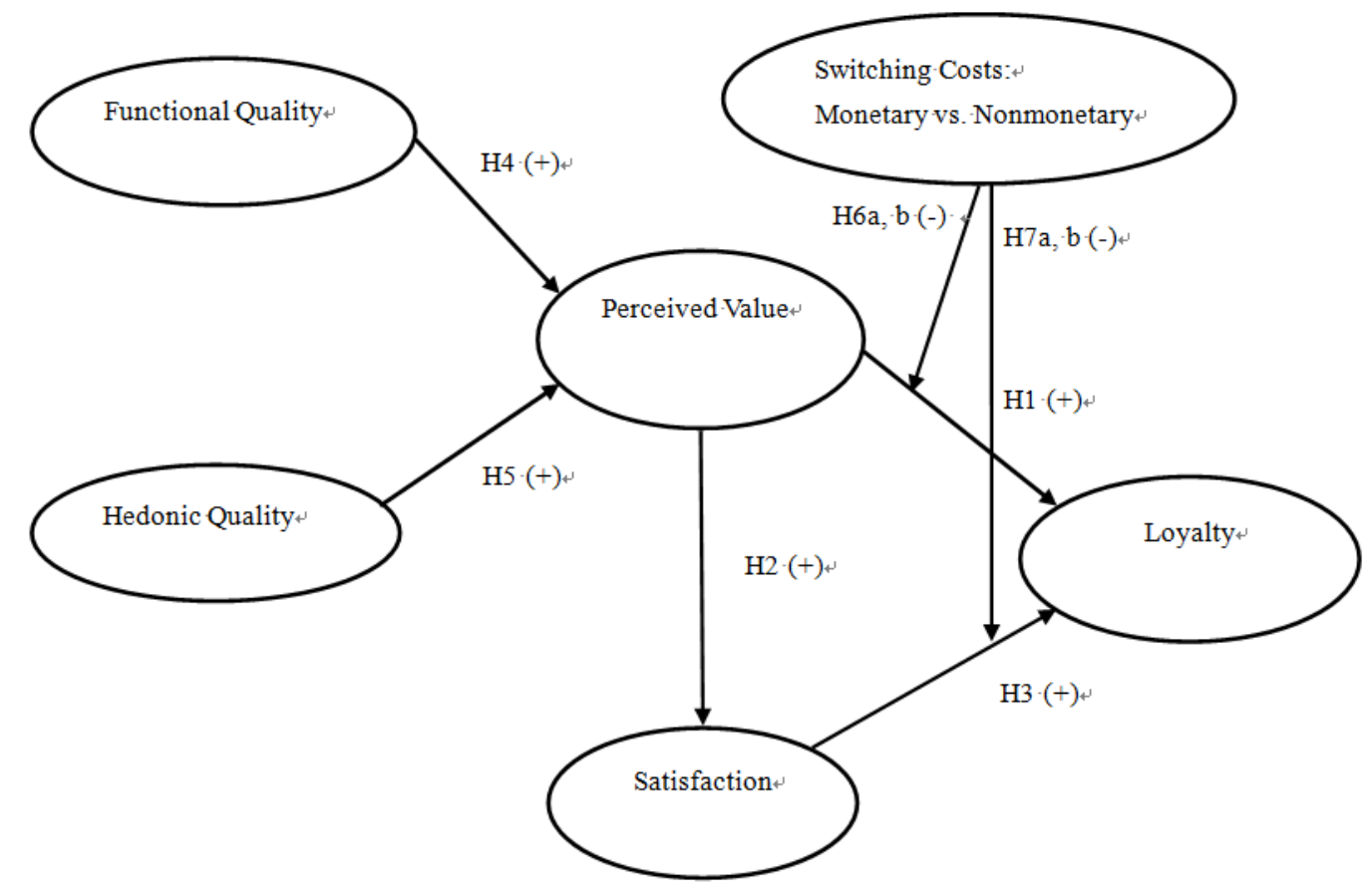

Fig. 1. Conceptual model of paid mobile applications.

\subsection{Measurement of Key Variables}

All items were measured on a five-point Likert scale, ranging from "disagree strongly" (1) to "agree strongly" (5). The measure of functional quality was adapted from a 4-item measure of Kim, Gupta and Koh (2011), whereas hedonic quality was modified from a 4-item measure of Bernardo, Marimon and del Mar Alonso-Almeida (2012). The items for monetary and nonmonetary switching costs were derived from Han and Ryu (2012). Appendix A presents a list of the items.

\subsection{Survey Instrument}

A self-administrated questionnaire was design to test the effect of value components on perceived value and influence on customer loyalty. In addition, it also examined the moderating effect of switching cost. The questionnaires were first checked by a panel of mobile game experts to assess whether there were misunderstandings or ambiguities in the expressions and to check for content validity. In an attempt to effectively establish the reliability of the measures, a pilot study for mobile customers was then conducted to deal with considerations such as instructional clarity, item clarity, and relevance.

\subsection{Procedure}

Respondents were first asked whether they had ever used paid mobile games. If they replied in the affirmative, they were asked to participate in the survey. The questionnaire requested the respondents to think back to the last time they had played mobile game through a mobile device and to answer the remaining questions accordingly. That is, respondents were asked to write down the name of the last mobile game they had used and paid for. The measurements of monetary switching costs (e.g., paying a higher price for services) and nonmonetary 
switching costs (e.g., taking a lot of effort) were included in the survey. The respondents were instructed to answer the questions by assessing that paid mobile game. For each question, respondents were asked to circle the response which best described their degree of agreement.

\subsection{Sample}

A sample consisted of 351 students enrolled in the eastern university in Taiwan. Selected participants were homogeneous groups who were relatively similar in terms of age (18-35 years) and education (undergraduates and graduates). Following the relevant study of Schilke and Wirtz's (2012), this study considered university students to be an appropriate sampling frame for three reasons: first, their role as innovators in adopting new technologies; second, their familiarity with computers and the Internet; and third, their use in theory testing and building. This study explained the purpose of the study to the students and provided them with basic background about broadband triple play.

\subsection{Analysis of Measure}

According to the two-step procedure established by Anderson and Gerbing (1988), the first step is to develop a measurement model with good fitness using confirmatory factor analyses (CFAs). Thus, in the first step, a confirmatory factor analysis (CFA) was performed to determine whether the measured variables reliably reflected the hypothesized latent variables (functional quality and hedonic quality).

In addition, convergent validity was examined through composite reliability. All composite reliability measures were .70 or higher, greater than the recommended level of .70, indicating adequate internal consistency. Convergent validity is generally considered to be adequate when constructs have an average variance extracted (AVE) of at least .50 (see Table 1).

Table 1. Correlations of latent variables and AVEs.

\begin{tabular}{|l|c|l|l|l|l|l|l|l|}
\hline Construct & Composite reliability & FUQ & HED & PV & SAT & LOY & MSC & NSC \\
\hline FUQ & 0.82 & 0.77 & & & & & & \\
\hline HED & 0.84 & $0.69^{*}$ & 0.76 & & & & & \\
\hline PV & 0.81 & $0.74^{*}$ & $0.58^{*}$ & 0.72 & & & & \\
\hline SAT & 0.84 & $0.50^{*}$ & $0.53^{*}$ & $0.45^{*}$ & 0.74 & & & \\
\hline LOY & 0.87 & $0.49^{*}$ & $0.43^{*}$ & $0.34^{*}$ & $0.40^{*}$ & 0.69 & & \\
\hline MSC & 0.86 & $0.33^{*}$ & 0.29 & $0.21^{*}$ & $0.32^{*}$ & $0.54^{*}$ & 0.75 & \\
\hline NSC & 0.83 & $0.30^{*}$ & $0.20^{*}$ & $0.19^{*}$ & $0.18^{*}$ & $0.28^{*}$ & $0.24^{*}$ & 0.71 \\
\hline
\end{tabular}

Notes: $* p<.05$. Values on the bold diagonal are the square roots of the AVEs.

For satisfactory discriminant validity, Table 2 also revealed that all AVE levels were greater than .50. Each construct meets this requirement, in support of discriminant validity. Also, the cross loadings were examined and each indicator's loadings were found to be greater than all of its cross loadings (Chin, 1998). Thus, a high degree of discriminant validity can be presumed with respect to all the constructs in this study. Based on these results, the items demonstrated satisfactory convergent and discriminant validity. 
Table 2. Fit statistics

\begin{tabular}{|l|l|l|}
\hline Fit measures & & Recommendation value \\
\hline$\chi^{2} / d . f$. & 2.43 & $<5.0$ (Bentler and Bonett, 1980) \\
\hline GFI & & \\
\hline AGFI & 0.93 & $\geq .90$ (Bentler, 1990) \\
\hline NFI & 0.90 & $\geq .90$ (Bentler, 1990) \\
\hline CFI & 0.91 & $\geq .90$ (Fornell and Larcker, 1981) \\
\hline RMSEA & 0.94 & $\geq .90$ (Hu and Bentler, 1999) \\
\hline Square multiple correlation & & \\
\hline Perceived value & 0.04 & $<.08$ (Brown and Cudeck, 1993) \\
\hline Satisfaction & 0.43 & \\
\hline Loyalty & 0.58 & \\
\hline
\end{tabular}

In the second step, a series of structural equation path models were tested in order to: (1) determine the perceived value-satisfaction-loyalty relationships of paid mobile games; (2) test how monetary switching costs and nonmonetary switching costs moderate the relationships among perceived value, satisfaction, and loyalty.

\section{Results}

The causal model was assessed using latent variable structural equation modeling in AMOS 19.0. However, past researchers (e.g., Hair et al., 1998) recommended that the $\chi^{2}$ measure should be complemented with other goodness-of-fit measures. The fitness of conceptual model from this analysis was chi-square/ $d f=2.43, p<.001$. Further, additional goodness-of-fit indices, including the goodness-of-fit index (GFI), the adjusted goodness-of-fit index (AGFI), the normed fit index (NFI), the comparative fit index (CFI), and the root mean square error of approximation (RMSEA), were all at acceptable levels, indicating that the model fit the data well (Bagozzi and Yi, 1988).

The values of the goodness-of-fit index (GFI) were above .90 for all the estimated models, indicating a good absolute model fit (Bentler, 1990). Values of AGFI above 90 indicate a very good fit (Bentler, 1990). The Bentler and Bonett normed fit index (NFI) showed values above .90. The values of CFI were above .95 for all the estimated models (Hu and Bentler, 1999). The estimations of RMSEA were less than .08, which indicated a reasonable fit of all the estimated models in relation to the degrees of freedom (Browne and Cudeck, 1993). Fit indices varied greatly in their reliability of estimation and sensitivity to sample size. In all, then, acceptable support was provided for the models as proposed.

On the other hand, the structural equation modelling also tested the validity of the conceptual model in predicting the paid mobile application loyalty customer; it explained $78 \%$ of the variation in the mobile application loyalty customer (i.e., $R^{2}$ ), showing a better explanatory power in the research setting. Further, about statistical hypothesis testing, as this study 
predicted in $\mathrm{H} 1$, perceived value was positively and significantly related to customer loyalty, with standardized $g$ coefficients of $0.38(p<0.001)$. Also, the result showed a positive relationship of perceived value to satisfaction $(\beta=.26, p<.001)$, in support of $\mathrm{H} 2$. In addition, satisfaction was positively correlated with customer loyalty $(\beta=.52, p<.001)$, providing support for $\mathrm{H} 3$. In addition, the antecedents significantly and positively affected perceived value $(\beta=.42, p<.001)$, showing that the impact of functional quality on perceived value was significant $(\beta=.64, p<.001$ ), in support of $\mathrm{H} 4$. H5 predicted a positive path from hedonic quality to perceived value.

\subsection{Metric Invariances}

Further, multiple-group analyses served to test the moderating effect of switching costs on the relationship among perceived value, satisfaction, and customer loyalty, and to test hypotheses $\mathrm{H} 6 \mathrm{a}, \mathrm{b}$ and $\mathrm{H7}$ a, $\mathrm{b}$ and their variations relating to the hypothesized effect of switching costs. This study also used $K$ means cluster analysis to split the respondents into groups, first based on high and low monetary switching costs and then on high and low nonmonetary switching costs. The high monetary cost group comprised 189 respondents, and the low group had 162 cases. For nonmonetary switching costs, the high group included 155 respondents and the low group had 196 cases. Following Steenkamp and Baumgartner's (1998) suggestion, this compared the confirmatory factor analysis without constraining any factor loadings across groups (nonrestricted model) as against the full-metric invariance model, in which all factor loadings were set to be invariant. Thus, the separate structural models for four subsamples and conducted tests of moderation were performed to determine whether the coefficients of the hypothesized paths differed. In a baseline model, this study allowed the effect of identification on consumer power to vary across groups. In the second model, to constrain this effect to be equal across subsamples. The path of perceived value and loyalty from identification to consumer power weakened in the high-score monetary switching costs compared with the low-score monetary switching costs subsample $(\beta=-.41, S . E .=.05)$

while the path of satisfaction and loyalty from identification to consumer power decreased in the high-score nonmonetary switching costs compared with the low-score nonmonetary switching costs subsample ( $\beta=-.57, .83$, S.E. $=.08$ ); thus, H6a,b and H7a, b were supported $\left(\Delta \chi^{2}=4.33, \Delta d f=1, p<.05\right)$.

\section{Discussion}

Although past research has investigated the relationship among perceived value, satisfaction, and customer loyalty, few work were clearly showed a significant mediating role of 
satisfaction between perceived value and customer loyalty, especially in the paid mobile application industry. This study also aims to discuss the antecedents of perceived value to further to demonstrate the components of perceived value.

The findings have several theoretical and managerial implications. From a theoretical perspective, this study makes important contributions to the mobile application literature on the moderating effects of switching costs. While the importance of switching costs has been widely discussed in the mobile commerce literature, little research has emphasized the significant moderating role of monetary switching costs and nonmonetary switching costs as key variables in explaining customer behavior (Han and Ryu, 2012). Extending the finding of Han and Ryu (2012), this study showed that the inclusion of switching costs in addition to perceived value and satisfaction in one model not only highlights the importance of perceived value and satisfaction but also provides a more comprehensive understanding of their moderating effects on the relationships among perceived value, satisfaction, and customer loyalty. This also suggests that perceived value, satisfaction and customer loyalty should be included when measuring customers' degrees of switching costs regarding using paid mobile application, particularly in the paid mobile game segment. Such as, perceived value, satisfaction, and customer loyalty differ across switching costs, as monetary switching costs mobile application users perceive value, satisfaction and loyalty more strongly than other nonmonetary switching costs segments.

For mobile application marketers, the study results suggested that developing positive indicators of perceived value relies not only on the service provider's ability to increase functional quality, but also to establish a favourable hedonic quality to enhance perceived value and satisfaction, then enhance customer loyalty. Moreover, because a service provider can create value for itself from a business relationship only if it supports its customer's perceived value creation, the process of functional quality and hedonic quality should be studied, and corresponding strategies for measuring such quality creation developed.

\subsection{Limitations and Future Research Directions}

Although this study has research contributions, it also has some limitations. First, some may argue that the exploratory clustering of consumers is a snapshot that is specific to both time and place. Findings might have been very different had I sampled these data at another time or in different places. To overcome this criticism, future researchers may wish to establish a panel that allows for continuous monitoring of the changes in experienced versus new paid mobile game users, as well as persistent mobile internet users versus those who have abandoned the mobile application platform. Second, this study used a sample of Taiwanese consumers from the young-adult segment. This may have introduced a bias. Finally, an another value perspective may lead to different degrees of perceived value, future research can extend to discuss the value components in explaining the mobile application adoption.

\section{References}

Ahn, Tony, Seewon Ryu, \& Ingoo Han (2007). The impact of Web quality and playfulness on 
user acceptance of online retailing, Information and Management, 44(3), 263-75. http://dx.doi.org/10.1016/j.im.2006.12.008

Anderson, James C., \& David W. Gerbing (1988). Structural equation modeling in practice: A review and recommended two-step approach, Psychological Bulletin, 103(3), 411-23. http://dx.doi.org/10.1037/0033-2909.103.3.411

Bagozzi, Richard P., \& Youjae Yi (1988). On the evaluation of structural equation models, Academy of Marking Science, 16(1), 76-94. http://dx.doi.org/10.1007/bf02723327

Baldinger, Allan L., \& Joe Rubinson (1996). Brand loyalty: The link between attitude and behavior, Journal of Advertising Research, 36(6), 22-35.

Bentler, Paul M. (1990). Comparative fit indexes in structural models, Psychological Bulletin, 107(2), 238-46. http://dx.doi.org/10.1037/0033-2909.107.2.238

Bentler, Paul M., \& Douglas G. Bonett (1980). Significance tests and goodness of fit in the analysis of covariance structures, Psychological Bulletin, 88(3), 588-606. http://dx.doi.org/10.1037/0033-2909.88.3.588

Bernardo, Merce, Frederic Marimon, \& María del Mar Alonso-Almeidac (2012). Functional quality and hedonic quality: A study of the dimensions of e-service quality in online travel $\begin{array}{llll}\text { agencies, } \quad \text { Information } \quad \text { \& } \quad \text { Management, } & \text { 49(7/8), }\end{array}$ http://dx.doi.org/10.1016/j.im.2012.06.005

Bolton, Ruth N., \& James H. Drew (1991). A longitudinal analysis of the impact of service changes on customer attitudes, Journal of Marketing, 55(1), 1-10. http://dx.doi.org/10.2307/1252199

Browne, Michael W., \& Robert Cudeck (1993). Alternative ways of assessing model fit," in: Bollen, K.A. and J.S. Long, eds., Testing Structural Equation Models, Newbury Park, CA: Sage; 136-62.

Burnham, Thomas A., Judy K. Frels, and Vijay Mahajan (2003). Consumer switching costs: A typology, antecedents and consequences, Journal of the Academy of Marketing Science, 31(2), 109-26. http://dx.doi.org/10.1177/0092070302250897

Chang, Nai-Jen \& Cher-Min Fong (2010). Green product quality, green corporate image, green customer satisfaction, and green customer loyalty, African Journal of Business Management, 4(13), 2836-44.

Chen, Ching-Fu \& Meng-Huan Tsai (2008). Perceived value, satisfaction, and loyalty of TV travel product shopping: Involvement as a moderator, Tourism Management, 29(6), 1166-71. http://dx.doi.org/10.1016/j.tourman.2008.02.019

Chin, Wynne W. (1998). The partial least squares approach to structural equation modeling, in Marcoulides, G.A. (Ed.), Modern Methods for Business Research, Mahwah, NJ: Lawrence Erlbaum Associates, 295-336.

Deng, Zhaohua, Yaobin Lu, Kwok Kee Wei, \& Jinlong Zhang (2010). Understanding 
customer satisfaction and loyalty: an empirical study of mobile instant messages in China, International Journal of Information Management, 30(4), 289-300. http://dx.doi.org/10.1016/j.ijinfomgt.2009.10.001

Dey, Anind K., Gregory D. Abowd, \& Daniel Salber (2001). A conceptual framework and a toolkit for supporting the rapid prototyping of context aware applications, Human-Computer Interaction, 16(2), 97-166. http://dx.doi.org/10.1207/S15327051HCI16234_02

Dick, Alan S., \& Kunal Basu (1994). Customer loyalty: Toward an integrated conceptual framework, Journal of the Academy of Marketing Science, 22(2), 99-114. http://dx.doi.org/10.1177/0092070394222001

Eggert, Andreas \& Wolfgang Ulaga (2002). Customer perceived value: A substitute for satisfaction in business markets, Journal of Business \& Industrial Marketing, 17(2/3), 107-18. http://dx.doi.org/10.1108/08858620210419754

Evanschitzky, H., Iyer, G.R., Hesse, J., \& Ahlert, D. (2004). E-Satisfaction: A re-examination, Journal Retailing, 80(3), 239-47. http://dx.doi.org/10.1016/j.jretai.2004.08.002

Fornell, Claes \& David F. Larcker (1981). Evaluating structural equation models with unobservable variables and measurement error, Journal of Marketing Research, 18(1), 39-50. http://dx.doi.org/10.2307/3151312

Fu, Bin, Jialiu Lin, Lei Liy, Christos Faloutsos, Jason Hong, \& Norman Sadeh (2013). Why people hate your app - Making sense of user feedback in a mobile app store," KDD'13, August 11-14, Chicago, Illinois, USA.

Fullerton, Gordon (2003). When does commitment lead to loyalty? Journal of Service Research, 5(4), 333-44. http://dx.doi.org/10.1177/1094670503005004005

Grönroos, Christian (2000). Service management and marketing: A customer relationship management approach, " 2nd ed., New York: John Wiley \& Sons Ltd.

Ha, Imsook, Youngseog Yoon, \& Munkee Choi (2007). Determinants of adoption of mobile games under mobile broadband wireless access environment, Information \& Management, 44(3), 276-86. http://dx.doi.org/10.1016/j.im.2007.01.001

Hair, Joseph F., Jr., Rolph E. Anderson, Ronald L. Tatham, \& William C. Black (1998), Multivariate Data Analysis, 5th ed., Englewood Cliffs, NJ: Prentice-Hall.

Han, Heesup \& Ryu, Kisang (2012). Key factors driving customers' word-of-mouth intentions in full-service restaurants: The moderating role of switching costs, Cornell Hospitality Quarterly, 53(2), 96-109. http://dx.doi.org/10.1177/1938965511433599

Hauser, John R., Duncan I. Simester, \& Birger Wernerfelt (1994). Customer satisfaction incentives, Marketing Science, 13(4), 327-50. http://dx.doi.org/10.1287/mksc.13.4.327

Holbrook, Morris B. (1999). Consumer Value: A Framework for Analysis and Research," London: Routledge. http://dx.doi.org/10.4324/9780203010679 
Hu, Li-Tze \& Paul M. Bentler, (1999). Cutoff criteria for fit indi-ces in covariance structure analysis: Conventional versusnew alternatives, Structural Equation Modeling, 6(1), 1-55. http://dx.doi.org/10.1080/10705519909540118

iOSpirations Statistics (2013), (accessed July 2013), [available at:] http://www.iospirations.com/top10-paid-ipad-apps/games.

Kim, Hee-Woong, Sumeet Gupta, and Joon Koh (2011). Investigating the intention to purchase digital items in social networking communities: A customer value perspective, Information \& Management, 48(6), 228-34. http://dx.doi.org/10.1016/j.im.2011.05.004

Kim, Moshe, Doron Kliger, \& Bent Vale (2003). Estimating switching costs: The case of banking, Journal of Financial Intermediation, 12(1), 25-56. http://dx.doi.org/10.1016/S1042-9573(02)00005-0

Kottari, Vikas, Vishwanath Kamath, Lloyd Presley Saldanha, \& Chandan Mohan (2013). A survey on mobile cloud computing: Concept, applications and challenges, International Journal of Advanced and Innovative Research, 2(3), 487-92.

Turban, Efraim \& David Neden King (2003). Introduction to e-commerce," Upper Saddle River, NJ: Prentice Hall.

Learn Everywhere (2012). Mobility is the future, (accessed December 2012), [available at]: http:// blog.learneverywhere.com/.

Lin, Hsin-Hui \& Yi-Shun Wang (2006). An examination of the determinants of customer loyalty in mobile commerce contexts, Information \& Management, 43(3), 271-82. http://dx.doi.org/10.1016/j.im.2005.08.001

Liu, C-H. \& S-L. Chou (2008). Analysis of Internet Entertaining Behaviors in Taiwan," Market Intelligence Center, Taipei.

Lu, Hsi-Peng \& Kuo-Lun Hsiao (2010). The influence of extro/introversion on the intention to pay for social networking sites, Information \& Management, 47(3), 150-57. http://dx.doi.org/10.1016/j.im.2010.01.003

Nguyen, Nha André Leclerc, \& Gaston LeBlanc (2013). The mediating role of customer trust on customer loyalty, Journal of Service Science and Management, 6(1), 96-109. http://dx.doi.org/10.4236/jssm.2013.61010

Oliver, Richard L. (1981). Measurement and evaluation of satisfaction processes in retail settings, Journal of Retailing, 57(3), 25-48.

Oliver, Richard L. (1999). Whence consumer loyalty, Journal of Marketing, 63(4), 33-44. http://dx.doi.org/10.2307/1252099

Penttinen, Esko, Matti Rossi, \& Virpi Kristiina Tuunainen (2010). Mobile games: Analyzing the needs and values of the consumers, Journal of Information Technology Theory and Application, 11(1), 5-22. 


\section{$\triangle$ Macrothink}

Business and Economic Research ISSN 2162-4860

Porter, Michael E. (1998). Competitive strategy: Techniques for analyzing industries and competitors, NY: Free Press.

Razavi, Seyed Mostafa, Hossein Safari, Hessam Shafie, \& Kobra khoram (2012). Relationships among service quality, customer satisfaction and customer perceived value: Evidence from Iran's software industry, Journal of Management and Strategy, 3(3), 28-37. http://dx.doi.org/10.5430/jms.v3n3p28

Reichheld, Frederick F., \& Phil Schefter (2000). E-loyalty: Your secret weapon on the web," Harvard Business Review, July-August, 105-13.

Sánchez-Fernández, Raquel and M. Ángeles Iniesta-Bonilla (2007). The concept of perceived value: A systematic review of the research, Marketing Theory, 7(4), 427-51. http://dx.doi.org/10.1177/1470593107083165

Satyanarayanan, Mahadev (2005). Swiss Army Knife or Wallet? IEEE Pervasive Computing, 4(2), 2-3. http://dx.doi.org/10.1109/MPRV.2005.39

Schilke, Oliver \& Bernd Wirtz (2012). Consumer acceptance of service bundles: An empirical investigation in the context of broadband triple play, Information \& Management, 49(2), 81-8. http://dx.doi.org/10.1016/j.im.2011.12.003

Shin, Choonsung, Jin-Hyuk Hong, \& Anind K. Dey (2012). Understanding and prediction of mobile application usage for smart phones, Proceedings of the 2012 ACM Conference on Ubiquitous Computing, NY: ACM, 173-82. http://dx.doi.org/10.1145/2370216.2370243

Steenkamp, Jan-Benedict E M., \& Hans Baumgartner (1998). Assessing measurement invariance in cross-national consumer research, Journal of Consumer Research, 25(1), 78-90. http://dx.doi.org/10.1086/209528

Sirdeshmukh, Deepak, Jagdip Singh, \& Barry Sabol (2002). Consumer trust, value and loyalty in relational exchanges, Journal of Marketing, 66(1), 15-37. http://dx.doi.org/10.1509/jmkg.66.1.15.18449

Sweeney, Jillian C., \& Geoffrey N. Soutar (2001). Consumer perceived value: the development of a multiple item scale, Journal of Retailing, 77(2), 203-20. http://dx.doi.org/10.1016/S0022-4359(01)00041-0

Szymanski, David M., \& Richard T. Hise (2000). E-satisfaction: An initial examination, Journal of Retailing, 76(3), 309-22. http://dx.doi.org/10.1016/S0022-4359(00)00035-X

Rayport, Jeffrey F., \& Bernard J. Jaworski (2003). Introduction to E-Commerce, New Jersey: Prentice Hall.

Turel, Ofir \& Alexander Serenko (2006). Satisfaction with mobile services in Canada: An empirical investigation, Telecommunications Policy, 30(5-6), 314-31. http://dx.doi.org/10.1016/j.telpol.2005.10.003

Yang, Zhilin \& Robin T. Peterson (2004). Customer perceived value, satisfaction, and loyalty: The role of switchinging costs, Psychology \& Marketing, 21(10), 799-822. 
http://dx.doi.org/10.1002/mar.20030

Waldner, Florian, Martin Zsifkovits, \& Kurt Heidenberger (2013). Are service-based business models of the video game industry blueprints for the music industry? International Journal of Services, Economics and Management, 5(1-2), 5-20. http://dx.doi.org/10.1504/IJSEM.2013.051862

Wei, Ran (2008). Motivations for using the mobile phone for mass communications and entertainment, Telematics and Informatics, 25(1), 36-46. http://dx.doi.org/10.1016/j.tele.2006.03.001

Zeithaml, Valarie A., Leonard L. Berry, \& A. Parasuraman (1996). Communication and control processes in the delivery of service quality, Journal of Marketing, 52(2), 35-48. http://dx.doi.org/10.2307/1251263

Appendix A. List of items by construct

Functional quality (Kim, Gupta, and Koh, 2011)

FQU1: The mobile games sold here have an acceptable standard of quality.

FQU2: The mobile games sold here are reliable in their performance.

FQU3: The mobile games sold here are good in terms of their overall excellence.

FQU4: The mobile games sold here possess a degree of quality which is satisfactory.

Hedonic quality (Bernardo, Marimon, and del Mar Alonso-Almeida, 2012)

HED1: I enjoy the multimedia information, suggestions, and recommendations provided to the customer on this mobile game.

HED2: I think it is great fun to browse this mobile game.

HED3: When interacting with this mobile game, I do not realize how much time has elapsed

HED4: I enjoy sharing comments and experiences from other players.

HED5: I really enjoy playing at this mobile game of the game developer.

Perceived Value (Lin and Wang, 2006)

PV1: The product/service of this paid mobile game is good value for money.

PV2: The price of this paid mobile game is acceptable.

PV3: The product/service of this paid mobile game is considered to be a good buy.

Satisfaction (Lu and Hsiao, 2010)

SAT1: I am satisfied with the experience of using this paid mobile game.

SAT2: I am pleased with the experience of using this paid mobile game. 
SAT3: My decision to use this paid mobile game was a wise one.

SAT4: My feeling with using this paid mobile game was good.

Loyalty (Lin and Wang, 2006)

LOY1: My preference for this paid mobile game would not willingly change.

LOY2: It would be difficult to change my beliefs about this paid mobile game.

LOY3: Even if close friends recommended another paid mobile game, my preference for this paid mobile game would not change.

LOY4: I will buy from this paid mobile game the next time I purchase the above-mentioned product/ service.

LOY5: I intend to keep purchasing the abovementioned products/services from this paid mobile game.

Monetary Switching Cost (MSC) (Burnham, Frels, and Mahajan, 2003; Han and Ryu, 2012; Yang and Peterson, 2004)

MSC1 If I switch to a new mobile game, I will not be able to use some services and benefits from this restaurant, such as coupons, gift certificates, and membership services.

MSC2 Switching to another mobile game will incur a monetary cost, such as no discounts, no special offers, and paying a higher price for foods than in this mobile game.

Nonmonetary switching cost (Burnham, Frels, and Mahajan, 2003; Han and Ryu, 2012; Yang and Peterson, 2004)

NSC1 Even if I have enough information, comparing the mobile games with one another takes a lot of energy, time, and effort.

NSC2 In general, it would be a hassle switching to another mobile game.

\section{Copyright Disclaimer}

Copyright for this article is retained by the author(s), with first publication rights granted to the journal.

This is an open-access article distributed under the terms and conditions of the Creative Commons Attribution license (http://creativecommons.org/licenses/by/3.0/). 